GRASAS Y ACEITES 65 (1)

January-March 2014, e010

ISSN-L: 0017-3495

doi: http://dx.doi.org/10.3989/gya.074113

\title{
Simultatenous determination of diacetyl and acetoin in traditional turkish butter stored in sheep's rumen (Karinyagi)
}

\author{
R. Gokce ${ }^{\mathrm{a}}, \mathrm{A}$. Akdogan $^{\mathrm{b}, \bowtie}, \mathrm{U}$. Divriklib ${ }^{\mathrm{b}}$ and L. Elci ${ }^{\mathrm{b}}$ \\ aPamukkale University, Faculty of Engineering, Food Engineering, 20017 Denizli-Turkey \\ bPamukkale University, Science \& Art Faculty, Department of Chemistry, 20017 Denizli-Turkey \\ Corresponding author: akdogan@pau.edu.tr
}

Submitted: 8 July 2013; Accepted: 14 October 2013; Published on line: 13/02/2014

\begin{abstract}
SUMMARY: Commercial Karinyagi (traditionally named karin) is made of cows' milk cream and is produced by filling butter in cleaned sheep's rumen. The effect of butter storage in sheep's rumen on the production of diacetyl and acetoin was investigated. These compounds were determined by GC-MS and they are the typical butter flavor commonly found in fermented dairy products. The modified method for the simultaneous extraction of diacetly and acetoin from butter samples was accurate and precise. The recoveries of diacetyl and acetoin were 94.7 and $110.8 \%$, respectively, while the detection limits were 1.83 and $0.51 \mathrm{mg} \cdot \mathrm{L}^{-1}$, respectively. The proposed method was applied for the monitoring of aroma compounds in Karin butter samples during different time intervals. The concentration of acetoin remained stable through 0-50 days while the concentration of diacetyl increased to $33.0 \mu \mathrm{g} \cdot \mathrm{g}^{-1}$ up to 40 days and remained constant through $40-50$ days.
\end{abstract}

KEYWORDS: Acetoin; Butter; Diacetyl; GC/MS

RESUMEN: Determinación simultánea de diacetilo y acetoína en mantequilla tradicional turca (Karin) almacenada en el rumen de oveja. El Karinyagi comercial (nombre tradicional Karin) está hecho de crema de leche de vaca, y producido llenando con mantequilla el rumen limpio de ovejas. Se ha investigado el efecto del almacenamiento de la mantequilla en el rumen de ovejas sobre la formación de diacetilo y acetoína. Estos compuestos son el típico flavor a mantequilla que se detecta comúnmente en los productos lácteos fermentados y han sido determinados mediante GC-MS. El método modificado para la extracción simultánea de diacetilo y acetoína en mantequilla resultó ser exacto y preciso y las recuperaciones de 94,7 y $110,8 \%$ respectivamente, mientras que los límites de detección fueron 1.83 y $0,51 \mathrm{mg} \cdot \mathrm{L}^{-1}$, respectivamente. El método propuesto se aplicó al control de compuestos aromáticos en Karin y muestras de mantequilla, durante diferentes intervalos de tiempo. La concentración de acetoína se mantuvo estable entre 0-50 días mientras que la concentración de diacetilo aumentó a $33,0 \mathrm{mg} \cdot \mathrm{g}^{-1}$ hasta 40 días y se mantuvo constante entre $40-50$ días.

PALABRAS CLAVE: Acetoína; Diacetil; GC/MS; Mantequilla

Citation/Cómo citar este artículo: Gokce R, Akdogan A, Divriklib U, Elci L. 2014. Simultatenous determination of diacetyl and acetoin in traditional turkish butter stored in sheep's rumen (Karinyagi). Grasas Aceites 65 (1): e010. doi: http://dx.doi.org/10.3989/gya.074113

Copyright: (C) 2014 CSIC. This is an open-access article distributed under the terms of the Creative Commons Attribution-Non Commercial (by-nc) Spain 3.0 Licence. 


\section{INTRODUCTION}

The production and consumption of fermented milk products have been increasing throughout the world (Macciola et al., 2008). In Turkey, butter is manufactured from two different fermented milk products, cream and yoghurt. Butters have been produced industrially or traditionally by two different methods ("yayik butter" and "karin butter") for centuries in Turkey. Industrial butter is packed with aluminum foil, plastic or paper wrap and stored, whereas Karin butter is stored in a goat or sheep's rumen as a traditional way in the Mediterranean and Aegean region of Turkey. The use of the rumen of sheep and goat allows air and water vapor permeability during the storage of dairy products such as butter and cheese, and is one of the oldest traditional preservation methods.

Karin butter is produced from the cream obtained from the milk cream of cows. For this aim, creams containing 70 to $80 \%$ fat are kneaded in a vessel with handles to remove any components except for fat. During the kneading process, the brine formed is discharged from the system by a discharging canal at the bottom of the vessel. After the brine is removed from the structure to a certain ratio, the butter in the vessel is washed with tap water at $18-20{ }^{\circ} \mathrm{C}$. The butter is salted so that the final product contains $2 \%$ salt after washed at least three times until the brine becomes clear. Kneading is continued for some time to obtain a homogenized dispersion of the salt. When the kneading operation is complete, the butter is left in cold storage for a night in blocks of $10 \mathrm{~kg}$. The next day, the butter is kneaded again to separate the water remaining in the structure as far as possible, to homogenize the added salt and to obtain a certain consistency for the filling operation. Water in the structure is removed by passing the kneaded butter through a spiral press before filling. The butter separated from its water is carefully filled into the moistened karin without allowing any air pockets to form. The butter filled into karin (rumen) is put on the market after it is stored in cold storage $\left(6-10^{\circ} \mathrm{C}\right)$ for at least 15 days. The storage period of karm butter does not usually exceed 3 months (Gökçe et al., 2010).

The fact that the butter packaged in this way is more aromatic than butters packed in a commercial way has been confirmed by consumers (Adam, 1971; Sağdiç et al., 2002; Seçkin et al., 2005; Gökçe et al., 2010; Gun and Simsek, 2011). There have been numerous articles dealing with the function of lactic acid bacteria in the improvement of flavor compounds in dairy products. In cultured butter, the main flavor compounds are usually assumed to be diacetyl and acetaldehyde with an acidic background provided largely by lactic acid (Green and Manning, 1982; Seitz, 1990; Brito, 1990; Urbach, 1995; Escamilla-Hurtado et al., 2005).

Diacetyl is a major flavor component of several fermented dairy products including cultured butter which is the final product of citrate metabolism by certain lactic acid bacteria such as Lactococcus lactis subsp. lactis biovar diacetylactis and Leuconostoc. Diacetyl is produced from the spontaneous oxidative decarboxylation of $\alpha$-acetolactate which can also be transformed into acetoin by $\alpha$-acetolactate decarboxylase or by spontaneous non-oxidative decarboxylation (Aymes et al., 1999; de Vos and Hugenholtz, 2004; Leroy and De Vuyst, 2004; Singh et al., 2006; Quintans et al., 2008; Mallia et al., 2008).

The determination of diacetyl and acetoin by standard methods typically involves the use of preconcentration by vacuum distillation, liquid-liquid extraction, solid phase extraction and more recently, purge and trap techniques (Frank et al., 2004). Recently, diacetyl in milk products has often been determined by a headspace technique coupled with gas chromatography, using flame-ionization or mass spectrometer detectors (Adahchour et al., 1999; Frank et al., 2004; Bartowsky and Henschke, 2004; Panseri et al., 2011).

Several techniques such high-pressure liquid chromatography (HPLC), spectrophotometric, fluorometric and capillary zone electrophoresis have been reported for the determination of diacetyl and acetoin (Bartowsky and Henschke, 2004; Ligon et al., 2008).

To the best of our knowledge, there are no reports on diacetyl and acetoin concentration in karin butter produced in a traditional way. Sheep rumen is used as packing material for karin butter protection which probably has some affects on the chemical and biochemical properties of the product such as the synthesis of diacetyl processes and increases in the formation of diacetyl.

In this study, the effect of butter storage in sheep's rumen on the productions of diacetyl and acetoin was investigated. These compounds were determined and monitored by GC-MS. The effect of storage time on their concentrations was also investigated.

\section{EXPERIMENTAL}

\subsection{Chemicals and samples}

Ultra-pure quality water (resistivity $18.2 \mathrm{M} \Omega \cdot \mathrm{cm}^{-1}$ ) obtained with a reverse osmosis system (Human Corp., Seoul, Korea) was used for cleaning and other related solutions in all experiments. Aceton and n-hexane for the GC-MS analysis were obtain from Sigma-Aldrich (France, $>99.9 \%$ HPLC grade) for the extraction and dilution solvent. Diacetyl (2,3-butanedione), acetoin (3-hydroxy-2-butanone) and 2,3-pentadione as internal Standard (IS) were purchased from Alfa aesar (Karlsruhe, Germany) and Merck (Holenbrunn, Germany), respectively. Stock standard solutions of $1 \mathrm{mg} \cdot \mathrm{mL}^{-1}$ were prepared by diluting aceton:n-hexane $(1: 1, \mathrm{v} / \mathrm{v})$ and then storing at $4{ }^{\circ} \mathrm{C}$. Fresh working solutions were prepared by appropriate dilution with aceton:n-hexane. 
Five butter samples were purchased from traditional local markets in Denizli-Turkey. All the samples were used in the wet form without any treatment.

\subsection{Instrument and chromatographic conditions}

Chromatographic analyses of aromatic compounds were performed using a split/splitless injector system (AOC 20s auto sampler with AOC 20i auto injector) gas chromatograph (Shimadzu GC 2010) coupled with a mass spectrometer (Shimadzu QP 2010). Ultra-pure helium was used as the carrier gas with a flow rate of $1.00 \mathrm{~mL} \cdot \mathrm{min}^{-1}$. The injection port was worked at $250{ }^{\circ} \mathrm{C}$ in the splitless mode with 1 min splitless time. A $1 \mu \mathrm{L}$ injection volume was used for each analysis and the syringe was washed with hexane after each injection. Separation was carried out by DB-WAX (60 m x $0.25 \mathrm{~mm}$ I.D. capillary column with a $0.15 \mu \mathrm{m}$ stationary film thickness) purchased from Agilent J\&W (USA). The oven temperature programme was as follows: initial temperature $40{ }^{\circ} \mathrm{C}$, increased by $7{ }^{\circ} \mathrm{C} \cdot \mathrm{min}^{-1}$ to $200{ }^{\circ} \mathrm{C}$ and held at this temperature for $1 \mathrm{~min}$.

Mass spectrometric parameters were set as follows: electron impact ionization with $70 \mathrm{eV}$ energy and $250{ }^{\circ} \mathrm{C}$ ion source and interface temperature. The MS system was routinely set in selective ion monitoring (SIM) mode with a solvent delay of $6.5 \mathrm{~min}$. All aromatic compounds were identified by their retention times on the chromatogram and their specific $\mathrm{m} / \mathrm{z}$ on the mass spectrum (Table 1 ). The quantification was based on peak area using one target and one at three qualifier ion (s). The dwell times were set depending on the number of ions per group and the peak widths of the analytes.

\subsection{Extraction of diacetyl and acetoin from butter samples}

The determination of diacetyl using the liquidliquid extraction procedure with acetone as a solvent was reported by Macciola et al., (2008). The same procedure for the simultaneous extraction of diacetyl and acetoin from butter samples was used in this study. $2.0 \mathrm{~g}$ of butter sample were transferred in eppendorf $(15 \mathrm{~mL})$ polyethylene tube. The butter was melted for 5.0 min at $40{ }^{\circ} \mathrm{C}$. Then, $0.1 \mathrm{~g} \mathrm{MgSO}_{4}$ was added to the melted butter sample, and spiked with $20 \mu \mathrm{g}$ of internal standard (2,3-pentadione). The tube was shaken for $30 \mathrm{~s}$ at $1600 \mathrm{rpm}$ by vortex (ZX Classic; Velp Scientifica, Usmate, Italy) for homogenization. For the extraction, $2 \mathrm{~mL}$ of acetone were added. The mixture solution was rapidly shaken for $30 \mathrm{~s}$ at $1600 \mathrm{rpm}$ by vortex. After centrifugation (EBA 20 centrifuge; Hettich, Tuttlingen, Germany) of the mixture solution for $5 \mathrm{~min}$ at $5000 \mathrm{rpm}$ the upper phase was filtered through a $0.20 \mu \mathrm{m}$ disposable syringe membrane filter (Sartorius AG, Göttingen, Gremany). The upper phase was transferred to a small sample vial using a micro-syringe. From the auto-sampler, $1.0 \mu \mathrm{L}$ of the upper phase was injected into the GC. The final concentrations of diacetyl and acetoin were calculated by the calibration method (Table 2).

\section{RESULTS AND DISCUSSION}

\subsection{Analysis of analytes by GC-MS}

Acetone of reagent grade quality was used as a solvent to dissolve diacetyl and acetoin, together. Acetone showed itself to be an optimal solvent

TABLE 1. Retention times and $\mathrm{m} / \mathrm{z}$ values of diacetyl, acetoin and internal standard compounds

\begin{tabular}{|c|c|c|c|c|}
\hline Molecular name & MW & Structure & $\begin{array}{l}\text { Retention time } \\
(\mathrm{min})\end{array}$ & $\begin{array}{c}\text { Fragment ions }(\mathrm{m} / \mathrm{z}) \text { for } \\
\text { SIM }\end{array}$ \\
\hline $\begin{array}{l}\text { Diacetyl } \\
(2,3 \text {-butanedione }) \\
\left(\mathrm{C}_{4} \mathrm{H}_{6} \mathrm{O}_{2}\right)\end{array}$ & 86.09 & & 7.13 & $44,86,87$ \\
\hline $\begin{array}{l}\text { Acetoin } \\
\text { (3-hydroxy-2- } \\
\text { butanone) } \\
\left(\mathrm{C}_{4} \mathrm{H}_{8} \mathrm{O}_{2}\right)\end{array}$ & 88.11 & & 10.78 & $43,45,88$ \\
\hline $\begin{array}{l}\text { 2,3-pentadione (I.S) } \\
\left(\mathrm{C}_{5} \mathrm{H}_{8} \mathrm{O}_{2}\right)\end{array}$ & 100.12 & 0 & 12.24 & $29,57,100$ \\
\hline
\end{tabular}


TABLE 2. Figure of merits and validation of the method

\begin{tabular}{|c|c|c|c|c|c|c|c|c|}
\hline Compound & $\begin{array}{l}\text { Regression equations } \\
\text { (R2) }\end{array}$ & $\begin{array}{l}\text { Regression equations } \\
\text { with internal standard } \\
\text { (R2) }\end{array}$ & $\begin{array}{l}\text { LOD } \\
\mu \mathrm{g} \cdot \mathrm{g}^{-1}\end{array}$ & $\begin{array}{l}\mathrm{LOQ} \\
\mu \mathrm{g} \cdot \mathrm{g}^{-1}\end{array}$ & $\begin{array}{l}\text { Added } \\
\mu \mathrm{g} \cdot \mathrm{g}^{-1}\end{array}$ & $\begin{array}{c}\text { Founded } \\
\mu \mathrm{g} \cdot \mathrm{g}^{-1}\end{array}$ & $\underset{\%}{\text { RSD }}$ & $\begin{array}{c}\text { Recovery } \\
(\mathbf{R} \%)\end{array}$ \\
\hline \multirow{3}{*}{ Diacetyl } & \multirow{4}{*}{$\begin{array}{l}Y=39003.3 x-40369.5 \\
\left(R^{2}=0.9983\right)\end{array}$} & \multirow{3}{*}{$\begin{array}{l}\mathrm{Y}=0.1415 \mathrm{x}+1.38 \\
\left(\mathrm{R}^{2}=0.9998\right)\end{array}$} & \multirow{3}{*}{1.83} & \multirow{3}{*}{5.55} & - & $7.2 \pm 0.7$ & 9.7 & - \\
\hline & & & & & 30 & $35.6 \pm 3.6$ & 10.1 & 94.7 \\
\hline & & & & & 60 & $63.8 \pm 8.7$ & 13.6 & 94.3 \\
\hline \multirow{5}{*}{ Acetoin } & & \multirow{5}{*}{$\begin{array}{l}\mathrm{Y}=0.1020 \mathrm{x}+0.99 \\
\left(\mathrm{R}^{2}=0.9966\right)\end{array}$} & \multirow{5}{*}{0.51} & \multirow{5}{*}{1.53} & 90 & $98.7 \pm 9.6$ & 9.7 & 101.7 \\
\hline & \multirow{4}{*}{$\begin{array}{l}Y=23183.5 x-4711.9 \\
\left(R^{2}=0.9983\right)\end{array}$} & & & & - & $3.2 \pm 0.2$ & 6.2 & - \\
\hline & & & & & 30 & $36.4 \pm 2.5$ & 7.0 & 110.7 \\
\hline & & & & & 60 & $57.6 \pm 7.4$ & 12.8 & 90.7 \\
\hline & & & & & 90 & $91.2 \pm 6.4$ & 7.0 & 97.8 \\
\hline
\end{tabular}

LOD: Limit of detection, LOQ: Limit of quantification.

for each compound, because the three compounds have a similar chemical structure, being ketones. According to Macciola et al., (2008) acetone also has a significant advantage in instantly precipitating milk proteins and colloids.

We employed the method of Macciola for the extraction from karin butter samples. We modified the method for diacetyl and acetion extraction. Butter contains of maximum 16\% water and $90 \%$ milk-butter. Because of the presence of water in butter samples, we added $\mathrm{MgSO}_{4}$ in range of $0.1-0.5 \mathrm{~g}$ for the adsorption of water and the supernatant became clearer. The acetone phase was decreased with the increase in the amount of $\mathrm{MgSO}_{4}$. The optimum amount of $\mathrm{MgSO}_{4}$ was found to be $0.1 \mathrm{~g}$. After the centrifugation of the acetone-butter$\mathrm{MgSO}_{4}$, fat, water phase and $\mathrm{MgSO}_{4}$ were well separated on the bottom of the tube and the acetone (upper phase) became clear. After the filtration with $0.20-\mu \mathrm{m}$ disposable syringe membrane filter, it was directly injected into GC-MS for analysis.
As shown in the GC-MS chart (Figure 1), diacetyl, acetoin and 2,3-pentanodione (I.S) were detected at the retention times of $7.13,10.78$ and $12.24 \mathrm{~min}$, respectively. Diacetyl and acetoin were identified by their specific charge to mass ratio $(\mathrm{m} / \mathrm{z})$ values in MS (Table 1). The quantification was based on the peak area using one target and two qualifier ions.

\subsection{Validation of the GC-MS method}

The corresponding calibration equation, correlation of determination $\left(\mathrm{R}^{2}\right)$ value, limits of detection (LODs), limits of quantification (LOQs) and recovery were calculated under the optimum conditions and the results are discussed in this section.

The liquid-liquid extraction (LLE) method allowed for the determination of the examined two compounds in the concentration range of $0.2-100 \mathrm{mg} \cdot \mathrm{L}^{-1}$ by GC-MS with and without internal standard. An internal standard is a chemical substance that is added in a constant amount to

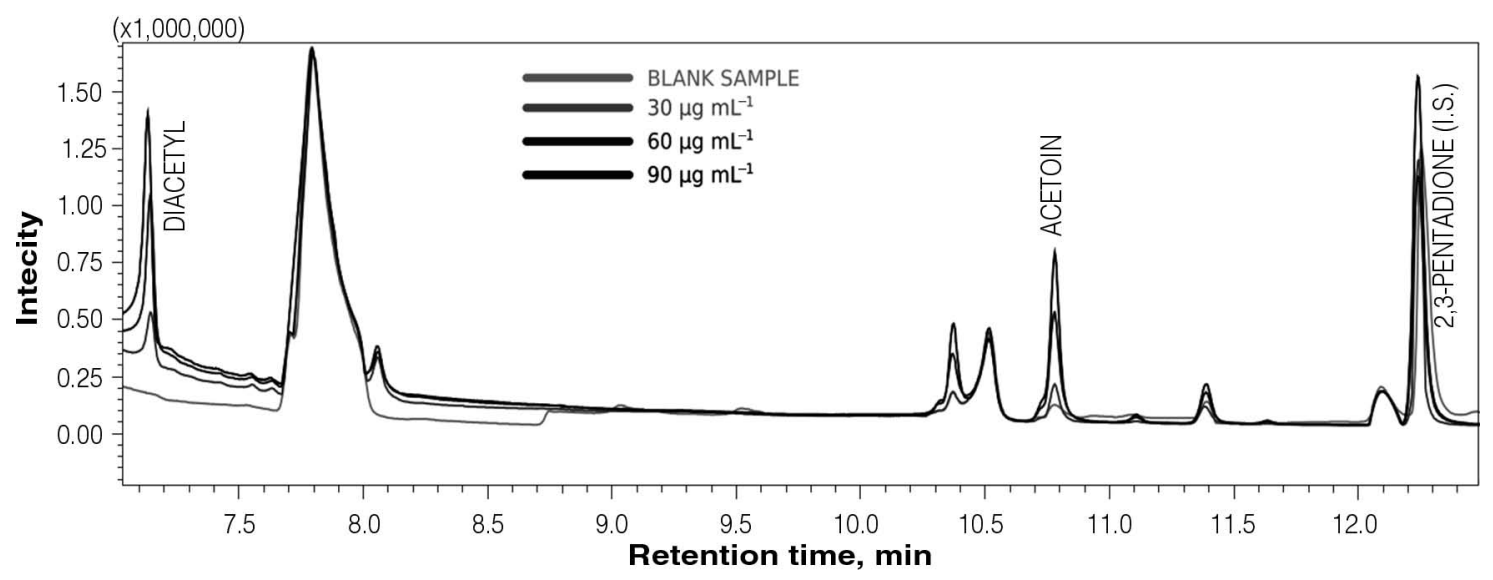

FIGURE 1. GC-MS chromatograms of diacetyl and acetoin in karin butter: without standard added (blank sample) and with standard added. 
samples, the blank and calibration standards in a chemical analysis. This substance can then be used for calibration by plotting the ratio of the analyte signal to the internal standard signal as a function of the analyte concentration of the standards. The calibration equations with and without internal standard are given in Table 2.

The reproducibility was studied in 16 replicate experiments. The good precision data for the determination of all the aromatic compounds without IS and with IS (RSD $<13.6 \%$ ) were obtained by extracting the butter samples spiked at 30, 60 and $90 \mu \mathrm{g} \cdot \mathrm{g}^{-1} \mathrm{lev}-$ els of each of compound (Table 2). The LODs, based on $\mathrm{S} / \mathrm{N}$ of 3 , were in 1.83 and $0.51 \mu \mathrm{g} \cdot \mathrm{g}^{-1}$ for diacetyl and acetoin, respectively. To validate the method procedure and investigate possible matrix effects, spiking recovery tests of two the compounds at concentrations of 30,60 and $90 \mu \mathrm{g} \cdot \mathrm{g}^{-1}$ from the butter samples were performed. The recoveries of diacetyl and acetoin from butter samples were achieved in the range of $90.7-110.7 \%$, which indicates that the procedure was free from matrix effects (Table 2). The chromatograms of the butter sample after performing the LLE method are displayed in Figure 1, prior and after the spiking of samples at 30,60 and $90 \mu \mathrm{g} \cdot \mathrm{g}^{-1}$ levels of each compounds and IS. Thus, the precision and accuracy of the GC-MS method was found to be satisfactory for the analysis of the karin butter samples.

\subsection{Evaluation of diacetyl and acetoin concentration in the karin butter samples}

In the final part of the research, the GC-MS method was used to determine diacetyl and acetoin in the karin butter samples. Diacetyl and acetoin determinations were carried out with four independent replicates. Mean, standard deviation (SD), analysis of variance (ANOVA), surface plot and the Tukey test were statistically analyzed by MINITAB 16.0 software (Minitab, State College, PA) at a significant level of 0.05 .

ANOVA was used to determine the significant differences in the concentrations of karin butter aroma compounds during the storage time of butter samples. Overall, the concentration of diacetyl in karin butter samples increased with the storage time. The concentration of acetoin in the same butter also fluctuated at different storage times, but there was no significant difference. For example, the samples analyzed from the karın butter at different storage times, the diacetyl concentrations at 20,30,40 and 50 days were $7.79,9.82,18.91$ and $20.85 \mu \mathrm{g} \cdot \mathrm{g}^{-1}$, respectively.

The results indicate that the two-way interactions of butter samples and storage time for the production of diacetyl and acetoin were statistically significant $(\mathrm{p}<0.05)$. Tukey's Honestly Significant Difference (HSD) test procedure appears to be more useful than ANOVA in the sense that it specifies which treatment means have a statistically significant difference. According to the Tukey test results, there were two groups for diacetyl and one group for acetoin. There were not differences between group (1) and group (2) for diacetyl ( $p>0.05$ ). The Butter sample and storage time for diacetyl and acetoin were statistically insignificant ( $p>0.05)$. On the contrary, according to the ANOVA results, the butter sample and storage time for diacetyl and acetoin were statistically significant $(\mathrm{p}<0.05)$. The experimental and statistical results are summarized in Table 3. The results show that the concentration of acetoin remains stable throughout the 50 days while

TABLE 3. Summary of statistical analysis for diacetyl and acetoin

\begin{tabular}{|c|c|c|c|c|c|c|c|c|c|c|c|c|c|c|c|}
\hline \multirow[b]{2}{*}{ Compound } & \multicolumn{7}{|c|}{ Summary of the results, $\left(\mu \mathrm{g} \cdot \mathrm{g}^{-1}\right)$} & \multicolumn{6}{|c|}{ Results of ANOVA } & \multicolumn{2}{|c|}{ Tukey test, $(\alpha ; 0.05)$} \\
\hline & Day & $\mathbf{N}$ & Mean & $\begin{array}{l}\text { Std. } \\
\text { dev. }\end{array}$ & $\begin{array}{l}\text { Std. } \\
\text { Error }\end{array}$ & $\begin{array}{l}\text { Min. } \\
\text { value }\end{array}$ & $\begin{array}{l}\text { Max. } \\
\text { value }\end{array}$ & & $\begin{array}{l}\text { Sum of } \\
\text { squares }\end{array}$ & $\begin{array}{l}\text { Degree } \\
\text { of } \\
\text { freedom }\end{array}$ & $\begin{array}{c}\text { Mean } \\
\text { squares }\end{array}$ & $\mathbf{F}$ & $\mathbf{P}$ & group, (1) & $\begin{array}{l}\text { group, } \\
\text { (2) }\end{array}$ \\
\hline \multirow{6}{*}{ Diacetyl } & 0 & 5 & 0.00 & 0.00 & 0.00 & 0.00 & 0.00 & & & & & \multirow{6}{*}{5.12} & \multirow{6}{*}{0.005} & & \\
\hline & 20 & 5 & 7.79 & 8.24 & 3.69 & 0.00 & 19.30 & Intergroup & 1455.4 & 4 & 363.8 & & & 7.79 & 7.79 \\
\hline & 30 & 5 & 9.82 & 5.47 & 2.44 & 5.74 & 16.11 & Intragroup & 1420.3 & 20 & 71.1 & & & 9.82 & 9.82 \\
\hline & 40 & 5 & 18.91 & 11.42 & 5.11 & 5.13 & 31.20 & Total & 2875.7 & 24 & & & & & 18.9 \\
\hline & 50 & 5 & 20.85 & 10.26 & 5.03 & 8.62 & 33.13 & & & & & & & & 20.8 \\
\hline & Total & 25 & 11.47 & 10.94 & 2.19 & 0.00 & 33.13 & & & & & & & (p: 0.38$)$ & (p: 0.14) \\
\hline \multirow{6}{*}{ Acetoin } & 0 & 5 & 8.14 & 0.34 & 0.15 & 7.58 & 8.45 & & & & & \multirow{6}{*}{3.25} & \multirow{6}{*}{0.033} & 8.14 & \\
\hline & 20 & 5 & 8.37 & 0.45 & 0.20 & 7.85 & 9.01 & Intergroup & 82.5 & 4 & 20.6 & & & 8.36 & \\
\hline & 30 & 5 & 8.64 & 0.55 & 0.24 & 7.92 & 9.42 & Intragroup & 126.9 & 20 & 6.3 & & & 8.64 & \\
\hline & 40 & 5 & 12.66 & 4.29 & 1.92 & 8.85 & 18.31 & Total & 209.4 & 24 & & & & 11.27 & \\
\hline & 50 & 5 & 11.27 & 3.57 & 1.60 & 9.12 & 17.36 & & & & & & & 12.66 & \\
\hline & Total & 25 & 9.82 & 2.95 & 0.60 & 7.58 & 18.31 & & & & & & & (p: 0.068) & \\
\hline
\end{tabular}




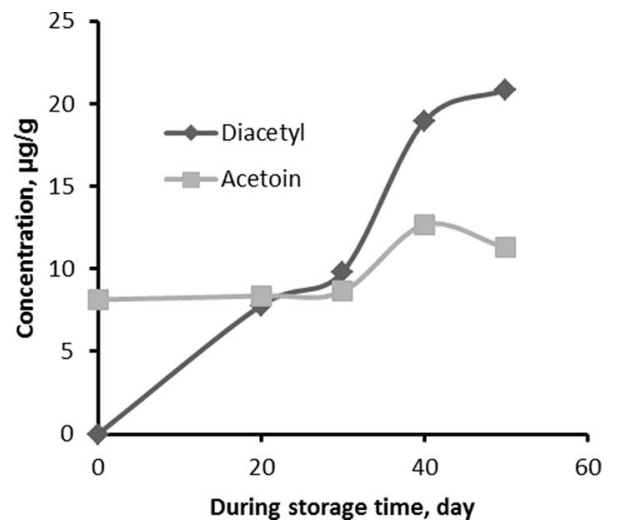

Figure 2. Relationship between storage time with concentration of diacetyl and acetoin.

the concentration of diacetyl increased to mean $20.85 \mu \mathrm{g} \cdot \mathrm{g}^{-1}$ up to 40 days and remained constant thereafter (Figure 2).

The contents of diacetyl were found to be dependent on storage time but the contents of acetoin rarely changed with storage time.

\section{CONCLUSIONS}

In this study, the main aroma compound contents of karin butter were determined and monitored by GC-MS. The recoveries of diacetyl and acetoin from butter samples were achieved in the range of 90.7$110.7 \%$ with relative standard deviations which were generally less than $13.6 \%$. This modified method was found to be comparatively more economical, faster, more precise and accurate for the simultaneous extraction of diacetyl and acetoin form butter samples.

The method could be used as a routine technique for the determination of diacetyl and acetoin in butter samples. Furthermore, the concentration of diacetyl in karin butter was increased with storage time, and then remained constant. The method used for the determination of diacetyl and acetoin was sensitive to changes in temperature, vapor pressure and sample matrix composition.

\section{ACKNOWLEDGMENTS}

We are grateful for the financial support of the Scientific Research Projects Unit at Pamukkale University (Project No. 2009 FBE 023).

\section{REFERENCES}

Adahchour M, Vreuls RJJ, van der Heijden A, Brinkmana UAT. 1999. Trace-level determination of polar flavour compounds in butter by solid-phase extraction and gas chromatography-mass spectrometry. J. Chromatogr. A. 844, 295-305.
Adam, RC. (1971) Süt III (Çeşitli ürünleri ve Artıkları). Ege University, Agricultural Faculty Press No. 170, Bornova-Izmir-Turkey.

Anonymous, 2005. Türk Gı̣da Kodeksi Tereyağı, Diğer Süt Yağı Esaslı Sürülebilir Ürünler ve Sadeyağ Tebliği (Tebliğ No: 2005/19), (Turkish).

Aymes F, Monnet C, Corrieu G. 1999. Effect of $\alpha$-Acetolactate Decarboxylase Inactivation on a-Acetolactate and Diacetyl Production by Lactococcus Zactis subsp. Zactis biovar diacetylactis. J. Biosci. Bioeng. 87, 87-92.

Bartowsky EJ, Henschke PA. 2004. The 'buttery' attribute of wine - diacetyl - desirability, spoilage and beyond. Int. J. Food Microbiol. 96, 235-252.

Brito CC. 1990. Lactic starters. Their influence on physical and sensory quality of cheese. Alimentos 15, 61-65.

De Vos WM, Hugenholtz J. 2004. Engineering metabolic highways in Lactococci and other lactic acid bacteria. Trends Biotechnol. 22, 72-79.

Escamilla-Hurtado ML, Valdés-Martínez SE, Soriano-Santos J, Gómez-Pliego R, Verde-Calvo JR, Reyes-Dorantes A, Tomasini-Campocosio A. 2005. Effect of culture conditions on production of butter flavor compounds by Pediococcus pentosaceus and Lactobacillus acidophilus in semisolid maize-based cultures. Int. J. Food Microbiol. 105, 305-316.

Frank DC, Owen CM, Patterson J. 2004. Solid phase microextraction (SPME) combined with gas-chromatography and olfactometry-mass spectrometry for characterization of cheese aroma compounds. Lebensm. Wiss. Technol. 37, 139-154.

Gökçe R, Aslanalp Y, Herken EN. 2010. Microbiological quality of karın butter, a traditionally manufactured butter from Turkey. Grasas Aceites 61, 121-125.

Green ML, Manning DJ. 1982. Development of texture and flavour in cheese and other fermented products. J. Dairy Res. 49, 737-748.

Gun I, Simsek B. 2011. The Fatty Acid Composition of Butter Stored in Sheep's or Goat's Stomach (Karinyagi). Food Nutrit. Sci. 2, 402- 406.

Leroy F, De Vuyst L. 2004. Lactic acid bacteria as functional starter cultures for the food fermentation industry. Trends Food Sci. Technol. 15, 67-78.

Ligon M, Jarmalaviciene R, Szumski M, Maruŝka A, Buszewski B. 2008. Determination of volatile and non-volatile products of milk fermentation processes using capillary zone electrophoresis and solid phase microextraction coupled to gas chromatography. J. Sep. Sci. 31, 2707-2713.

Macciola V, Candela G, De Leonardis A. 2008. Rapid gaschromatographic method for the determination of diacetyl in milk, fermented milk and butter. Food Control 19, 873-878.

Mallia S, Escher F, Schlichtherle-Cerny H. 2008. Aroma-active compounds of butter: a review. Eur. Food Res. Technol. 226, 315-325.

Panseri S, Soncin S, Chiesa LM, Biondi PA. 2011. A headspace solid-phase microextraction gas-chromatographic massspectrometric method (HS-SPME-GC/MS) to quantify hexanal in butter during storage as marker of lipid oxidation. Food Chem. 127, 886-889.

Quintans NG, Blancato V, Repizo G, Magni C, López P. 2008. Citrate metabolism and aroma compound production in lactic acid bacteria. Mol. Aspects Lactic Acid Bacteria Tradit. New Appl. 65-88.

Sagdiç O, Arici M, Simsek O. 2002. Selection of starters for a traditional Turkish yayik butter made from yoghurt. Food Microbiol. 19, 303-312.

Seçkin AK, Gürsoy O, Kınık Ö, Akbulut N. 2005. ConjuGated Linoleic Acid (CLA) Concentration, Fatty Acid Composition and Cholesterol Content of Some Turkish Dairy Products. Swiss Soc. Food Sci. Technol. 38, 909-915.

Seitz EW. 1990. Microbial and enzyme-induced flavors in dairy foods. J. Dairy Sci. 73, 3664-3691.

Singh SK, Ahmed SU, Pandey A. 2006. Metabolic engineering approaches for lactic acid production. Process Biochem. 41, 991-1000.

Urbach G. 1995. Contribution of lactic acid bacteria to flavour compound formation in dairy products. Int. Dairy J. 5, 877-903. 